\title{
Advance Pricing Arrangements as a Tax Strategy Tool for Related Entities
}

\author{
Karolina Kuropka*
}

\begin{abstract}
:
The article presents the procedure of concluding an advance pricing agreement between the taxpayer and the tax authority as a tool of tax strategy of large international groups. It was pointed out that the advance pricing agreement may be a key tool to protect affiliates operating in different tax jurisdictions from the questioning of market conditions in their transactions by tax administrations. The essence and stages of concluding this agreement are presented on the basis of the tax practice applied in Poland. In addition, special attention was paid to issues concerning properly implemented tax strategy in large international capital groups. The content of the article indicates certain benefits of establishing an advance pricing arrangement and its impact on the tax strategy in a capital group.
\end{abstract}

Key words: Tax law; Advance pricing arrangement; Related entities; Transfer prices; Tax strategy.

JEL classification: M21; M40; M48.

\section{Introduction}

While carrying out a variety of transactions, economic entities repeatedly take decisions, both nationally and internationally, in uncertain economic circumstances. A critical element of the environment of each economic entity is the fiscal environment, which also undergoes constant modifications, adapting to the dynamically changing economic reality. Moreover, one of the objectives of business entities operating in a competitive environment is to maximise their profits. A common practice supporting this objective is the use of a network of connections of entities, in particular capital, personal or organisational connections. Implementation of these activities is often of a strategic nature, affecting the entire capital group. However, it should be stressed that organised cooperation between related entities is also an element of interest of tax authorities

Karolina Kuropka; Wroclaw University of Economics and Business, Faculty of Business and Management, Department of Financial Accounting, Taxes and Auditing, Komandorska 118-120 Street, 53-345 Wrocław, Poland, <karolina.kuropka@ue.wroc.pl>. ORCID: 0000-0001-96957787. 
all over the world. Moreover, transactions concluded between related parties are often associated with the necessity to prepare transfer pricing tax documentation. In this respect, related parties may use certain tools to protect them against negative tax consequences. Their use is also part of the company's planned tax strategy. One of such tools limiting tax risk is an advance pricing arrangement, which is concluded between the taxpayer and the tax administration of a given country.

The purpose of this article is to present the pricing arrangement as a tool of tax strategy of related entities operating within an international capital group. The article characterises the essence of an advance pricing agreement and indicates the possibility of its application on a national and international scale. Moreover, the possibilities and effects of implementation of tax strategy planning tools by business entities were presented. The article results in a piece of research indicating the awareness of internationally operating economic entities of the benefits to be obtained following an implementation of the advance pricing arrangement for a given transaction. The article uses research methods of literature studies, analysis of accounting documentation, and a survey conducted with the personnel of analysed companies who get involved in the development of tax strategy in the analysed companies.

\section{The Essence of the Advance Pricing Arrangement}

Advance Pricing Arrangement (hereafter also APA) is an institution of international law aimed at implementing the provisions of double taxation conventions. It is a decision issued by a tax administration which indicates that the agreed transfer price for the transaction meets market conditions, i.e. complies with the arm's length principle (Kaniewska-Środecka, 2018). A prior price agreement is aimed at securing the tax interests of both the taxpayer and the tax administration. It is legally based on provisions of the concluded agreements for the avoidance of double taxation, which are modelled on Articles 9 and 25 of the OECD Model Tax Convention on Income and on Capital (Kosierdzki et al., 2019). The first of the above mentioned provisions of the Model Convention obliges to introduce the arm's length principle in the executed transactions, while the second gives the parties to the double taxation conventions a tool to communicate in order to avoid or evade it. Moreover, rules for interpretation of these provisions are included in the commentary to the Model Convention and in the OECD Transfer Pricing Guidelines for Multinational Enterprises and Tax Administrations. Chapter IV of the OECD Guidelines - Administrative Approaches to Avoiding and Resolving Transfer Pricing Disputes, outlines the procedure for implementing APA in related parties (OECD, 2017a). 
Three possible forms of APA conclusion are currently indicated. These are:

- unilateral agreement - concluded between the taxpayer and the tax authority. This agreement allows for a total or partial reduction of tax risk in relation to transactions concluded between domestic entities. This procedure does not guarantee the elimination of double taxation. However, it is no less advantageous for taxpayers due to the shortest time of the whole procedure.

- bilateral agreement - implemented between two countries. This agreement aims at minimising the tax risk in relation to a transaction between a domestic and a foreign entity. Moreover, the conclusion of this agreement is to eliminate the risk of double taxation.

- multilateral agreements - introduced between several countries. It is a solution dedicated to transactions characterised by the highest level of complexity. This agreement limits the risk of double taxation between domestic and foreign entities (Szpadzik, 2019).

It is important to stress that also the APA procedure may potentially end up being a very beneficial tool, the mere fact of going through the whole process can be burdensome for the taxpayer. Indeed, from the perspective of the number of obligations that an affiliate is faced with when applying for the APA, it can be concluded that the preparation and submission of the application itself is an extremely complex procedure. Steps 1 to 5 shows the procedure for concluding the APA based on Polish tax regulations.

\section{Step 1}

A preliminary meeting between representatives of the Ministry of Finance and representatives of the taxpayer during which practical and formal issues of applying for the APA can be consulted.

\section{Step 2}

Submission of a request for agreement by the taxpayer.

\section{Step 3}

Analysis of conditions established between the related parties on the basis of the submitted application and the material collected during the proceedings. At this stage, negotiations between the taxpayer and the tax administration body also take place.

\section{Step 4}

In the case of a unilateral agreement, a decision terminating the proceedings shall follow. 
In the case of a bilateral or multilateral agreement, negotiations take place with competent tax authorities of the transaction parties based on relevant provisions of the double taxation treaties. This should result in an agreement between the tax administrations.

\section{Step 5}

If the foreign tax authority does not agree to the pricing arrangement or if there is a high probability that no agreement will be reached, the tax authority shall inform the taxpayer of this fact. In such a case, the taxpayer may withdraw the application or amend the application for a bilateral agreement to conclude a unilateral agreement. Where only one foreign tax authority consents to the conclusion of an agreement and the taxpayer has applied for a multilateral arrangement, it may amend it to a bilateral agreement. At this stage, a decision terminating the procedure is issued. (Ministry of Finance in Poland, 2018).

As the table above shows, effective legislation on the APA procedure is a necessity to obtain the APA decision within a time frame that suits the taxpayer and the tax authority. Consequently, tax interests of both parties are safeguarded.

\section{Corporate Tax Strategy}

Economic entities acting both individually and in large international groups must take into account the prevailing economic conditions when carrying out transactions. The impact of both internal and external environment determines the chances of their prosperity and survival on the market. One of the sensitive elements of the external environment affecting activities of business entities is the tax system in place. Therefore, these entities pay ever increasing attention to the adoption of an appropriate tax strategy, both on the national and international scale, to allow them to operate effectively and efficiently and thus reduce the risk of making wrong decisions (Biernacki, 2017).

It should be emphasised that a company's tax strategy is a conscious set of decisions containing relevant objectives and the means to achieve them. Its proper implementation allows optimising the tax burden. Moreover, choosing the right tax strategy allows meeting the requirements of competitors and clients. For most capital groups, these aspects determine the fundamental objectives of which they intend to achieve and the directions of their activities. It should also be stressed that the tax strategy in its essence must consider and support the overall strategy of the company. The literature presents many types of tax strategies implemented by business entities. In this respect, conservative and aggressive strategies are mentioned, among others (Walicka, 2012). 
A conservative strategy is based on a precautionary approach to the implementation of tax obligations. This strategy focuses on avoiding disputes with the tax administration and making decisions that ensure tax security. A conservative company focuses on correct identification of its tax obligations and does not seek to minimise its tax burden.

The second in the list of indicated strategies represents fulfilling tax obligations while using any legal possibilities to minimise the tax burden. However, this strategy pays attention to the limitations resulting from the overall strategy of the business entity. In this area, the taxpayer should choose a course of action so that the main objective is achieved with the lowest possible tax burden (Mikrut and Poznańska, 2009).

It should be noted that the tax burden should be of a magnitude that is influenced and appropriately shaped. This is possible thanks to the knowledge of tax tools, optimisation schemes and structures. Their correct and legal use in practice may result both in the achievement of the objectives of business entities and the reduction of the tax burden.

\section{The APA Procedure and its Directions for Change in the Context of Strategic Planning by International Capital Groups}

The BEPS project initiated by the OECD and the group of the most industrialised countries- the G20- has particularly influenced the shaping of economic strategy by international corporations. One of the reasons for the implementation of this project were the tax planning strategies adopted by international business entities, which aimed to take advantage of the differences and loopholes in tax systems in different countries. (Flipsen and Duteweert, 2014) Activities of these entities have boiled down to the transfer of profits to jurisdictions with low tax rates or reduced transaction taxation conditions. Therefore, in order to counteract excessive abuse in this area, the OECD has developed the BEPS package as a policy including minimum standards, guidelines, good practices and common solutions for cross-border income taxation. The objective of these solutions is to reduce the erosion of the tax base through income taxation in those jurisdictions where value added is generated by transactions (OECD, 2017b). In this respect, it is safe to say that the BEPS project has directly and indirectly influenced the situation of multinational companies, including the strategic planning of their international activities. It is also crucial that the project has also influenced the activities of the tax authorities by introducing new rules, tools or modifications to existing tax systems. It is worth noting that meeting the objectives of the BEPS project is still a significant challenge for tax administrations, but its gradual implementation in OECD legislation will allow 
for adequate taxation of the supply chain created by international entities.(OECD, 2017a) It should also be emphasized that in this respect an already functioning institution, whose role has significantly increased as a result of the BEPS project, and which inevitable changes await, is the procedure of concluding previous price agreements (APA) discussed in this article.

In this regard, it should be noted that the APA is a tool that economic entities increasingly take into account as part of their tax strategy. This is due to the fact that it confirms that the correct transfer pricing method has been selected. In general, after issuing an APA decision, tax authorities cannot challenge the level of marketability in a related party transaction, assuming the terms and circumstances of the transaction outlined in the application remain unchanged. (Afik and Lahav, 2016) In the case of Polish legal solutions, an unquestionable benefit for the taxpayer is also the exemption from the documentation obligation in respect of transactions covered by the APA. Therefore, these benefits translate into increased interest of international enterprises in concluding this agreement.

It should be noted that, in the context of the BEPS project, bilateral and multilateral procedures are becoming increasingly important, indicating greater certainty in relation to the elimination of double taxation or non-taxation of multinational companies. This position is linked to the emergence of negative views on the tax interpretations of the transactions concerned and the unilateral pricing arrangements used by some taxpayers as a tool to achieve lower or nontaxation (Eden and Byrnes, 2018). Furthermore, the negative perception of certain types of APAs has been reinforced by the European Commission's investigations into unauthorised State aid and information leaks. It is worth noting that the allegations made by the European Commission have not always been upheld as correct, as evidenced, for example, by the judgment of the Court of Justice of 14 February 2019, (T-131/16, Belgium v Commission, EU:T:2019:91Court of Justice of the European Union, 2019). In this case, Belgium won in a procedure concerning illegal state aid in the form of use of the so-called 'excessive income mechanism.

In addition, for the strategic planning of international corporations certain directions of changes that await the price agreement procedure are also of key importance. In this regard, particular attention is paid to strengthening the benefits of having APA by economic entities, including:

- a recommendation to introduce bilateral APAs (in tax systems where the procedure is not yet operational) assessed as an instrument to reduce the risk of double taxation and to prevent future international conflicts and inconsistencies in the agreement procedure, 
- for countries that have already implemented a bilateral APA programme, the requirement for countries to consider introducing retroactive action by the APA subject to the possibility of limitation,

- a recommendation to establish internal guidelines for a multilateral procedure for mutual communication between countries.

In addition, another area for attention should be the development of practical guidelines for taxpayers to negotiate and implement bilateral or multilateral APAs. These guidelines should address both specific sectors and the business community at large, taking into account past agreements and clarifying the roles and responsibilities of taxpayers within the APA process. In this respect, these guidelines should be seen as positive since their implementation will increase the speed and efficiency of the APA process. It should also be stressed that the Organisation for Economic Cooperation and Development will also examine whether bilateral and multilateral APAs can be used in standard, pre-defined situations. First of all, it is pointed out that:

- agreements for specific industries concluded where the industry concerned operates in a typical homogeneous environment. This is already the case, e.g. in the Dominican Republic for the hotel industry, and in Mexico for manufacturing and its effects are assessed positively,

- taking into account the circumstances resulting from the increasing number of bilateral and multilateral agreements concluded in which the countries concerned have succeeded in developing acceptable profit-sharing formulas for the transactions concerned. In this case, OECD studies are to be targeted to determine whether schemes indicating the correct application of methods and margins can be developed on the basis of the data collected, once a case is deemed to fit a given transaction pattern(OECD, 2017a)

It should be noted that both Member States and entities participating in public consultations positively responded to these lines of action. In particular, issues related to the need to speed up and simplify proceedings for renewal or extension to past periods and the development of practical guidelines have been unanimously approved. Nevertheless, various proposals are already being made with regard to the details, as attention was also paid to the role of taxpayers in the APA process, including their will and ability to cooperate in the process of concluding agreements. Incomplete, rudimentary information and delays in providing it to tax administrations in the course of proceedings significantly affect the extension of the duration of the APA procedure. In addition, it was pointed out that the fast path to obtaining unilateral APAs may result in a reduction in the burden of proof and incomplete analysis of the facts. All this is superimposed by negative 
experiences related to unauthorized public aid of some countries, which was manifested by issuing unilateral tax interpretations or APA sanctioning nonmarket conditions.

Moreover, some of the proposed solutions may give rise to concerns, in particular with regard to simplified or standardised procedures. In this respect, Member States have indicated that the use of standard ranges is not, in principle, in line with the arm's length principle, since in most cases it is not possible to define such a standard range, but only a range appropriate to the specific transaction. On the other hand, trying to define standard ranges on the basis of one or even more agreements already concluded carries an even greater risk of not complying with the arm's length principle.

With these solutions and directions for change in mind, the APA is an important tool in developing a tax strategy for multinational companies. The optimisation of procedures, increasing the possibilities of examining applications, as well as the joint development of new, faster paths for reaching agreements on bilateral and multilateral matters is one of the key aspects of tax planning and setting out the directions of activities of multinational companies. In this respect, the protection offered by agreements to entrepreneurs in the context of a dynamically changing economic environment is also important. The negotiation nature of the APA procedure also plays an important role here as taxpayers have a significant influence on the ongoing proceedings, but it should also be noted that these entities must thereby adapt their business models to the requirements of the tax authority. Furthermore, it is worth noting that the implementation of changes to the APA will be a challenge both for internationally active affiliates but also for the tax administration itself which should then be required to implement procedures to increase their ability to process applications and to jointly develop effective pathways to agreement in bilateral and multilateral cases.(Szpadzik, 2019)

\section{Using the APA as a tool for tax strategy in a capital group - case study}

The use of available tax tools by economic operators is becoming more and more important each year due to their nature of protecting the interests of the taxpayer. Therefore, they are increasingly being implemented as strategic tools for businesses. In order to examine the use of APA as a tool for tax strategy, a survey was carried out covering the period from September to November 2019. The questionnaire was sent to 15 enterprises operating in Poland and in international capital groups. 11 of them replied to the questionnaire. These companies are related to entities from the Czech Republic, Germany, France and the Netherlands. Two of the surveyed entities concluded the APA in 2018 
for transactions concerning transfer of intangible assets between countries. The remaining nine respondent entities prepare transfer pricing tax documentation. The target group responding to the survey were people employed in these entities in the departments responsible for preparing transfer pricing tax documentation. Depending on the individual enterprise, these were departments of the controlling, accounting or separate organisational units whose sole task is to prepare transfer pricing tax documentation. In addition, these personnel declared within the survey that any doubt as to market conditions and transaction prices were consulted with senior managers responsible for the development of the plant in Poland. It is worth noting that each of these entities consults the terms of the transaction with independent tax advisers.

The survey included YES/NO questions:

1. Are tax optimisation measures applied in the capital group to which you belong?

2. Are the measures taken to reduce tax risks strategic long-term?

3. Does your company benefit from tax advantages of a double tax treaty?

4. Does the geographical location of your company's registered office have an impact on the amount of transfer prices set in the capital group?

5. Do you think that the APA is a tool which sufficiently safeguards the transaction against negative tax consequences?

6. In your opinion, can the conclusion of an APA increase the efficiency of the group and significantly increase the value of the group as a whole?

7. Do you see in your company the necessity to carry out a tax risk analysis in the aspect of transactions between related parties?

As a result of the surveys, the possibilities of using the APA and its impact on the strategic activities of the related parties in the capital group were identified. The responses indicate that most of them apply optimisation measures to reduce tax liabilities. Moreover, as a result of the research carried out, it was determined that $70 \%$ of the analysed entities implement long-term strategic actions aimed at reducing tax risk. Further questions related to the use of preferences resulting from double taxation treaties indicated that $60 \%$ of the surveyed companies use this type of preferences and 55\% of the surveyed business entities indicated that the decision on the geographical location of the company's registered office has an impact on the amount of established transfer prices in the capital group. The research shows that for $70 \%$ of the surveyed companies, the APA is a tool that sufficiently safeguards the transaction against negative tax consequences and $90 \%$ of the surveyed entities said the APA has an impact on the efficiency and increase 
in value of the group. The results of the survey show that $85 \%$ of the surveyed entities see the need for a tax risk analysis in transactions between related parties.

As the above results show, operators implementing optimisation measures are aware of the APA benefits. Indeed, the surveyed entities are of an opinion that on one hand it is important to achieve satisfactory financial results that increase the value added of the capital group and on the other hand they every time see the need for a risk analysis of their intra-group activities. The APA tool can be used by these entities to hedge the key intra-group transactions they carry out. Therefore, the conclusion of a prior price agreement allows within a certain period of time for:

- increasing the security of running a business,

- elimination of uncertainty resulting from possible tax proceedings in the field of transfer prices,

- elimination of the risk of penalties being imposed on the taxpayer and avoiding a lengthy tax audit process.

Therefore, obtaining the APA by a taxpayer eliminates the risk of potential future tax disputes with the tax authorities. This is a very important advantage, especially for taxpayers who are involved in complex intra-group transactions where it is difficult to determine the functions and risks of the entities involved. This issue is also very important, e.g. from the perspective of taxpayers carrying out restructuring of their activities.

In addition, the APA makes it possible to reduce or eliminate the risk of double taxation altogether by the option to establish a bilateral or multilateral agreement between the taxpayer and the tax administrations of two or more countries. This is possible because the APA negotiation process involves tax administrations within all the countries concerned.

The results of this survey are worth comparing with the evaluation of the APA in Poland. In this respect it should be noted that APA have been in place in the Polish law since 2006 and therefore this is not a new tool that Polish taxpayers can use. Data on the number of pricing agreements concluded between 2006 and 2019 are shown in table 1.

In the first years of the APA in Poland this tool was not very popular. Furthermore, it should be noted that initially there were only unilateral agreements. The first (two) bilateral APA were signed only in 2011 and the multilateral ones in 2014. Undoubtedly, the increase in unilateral pricing agreements was influenced by changes in the Polish tax regulations which significantly increased documentation obligations. The most significant changes 
in this respect occurred in 2017 and then in 2019, requiring taxpayers to conduct a thorough analysis of comparative data for the documented transaction. At the same time, the possibility of applying for an exemption from the preparation of transfer pricing tax documentation for a transaction to entities that have entered into the APA agreements was implemented.

Tab. 1 Information on statistics on concluded advance pricing agreements in Poland.

\begin{tabular}{ccccc}
\hline Year & APA unilateral & APA bilateral & APA multilateral & Total \\
\hline 2006 & 1 & 0 & 0 & 1 \\
2007 & 2 & 0 & 0 & 2 \\
2008 & 6 & 0 & 0 & 6 \\
2009 & 2 & 0 & 0 & 2 \\
2010 & 7 & 0 & 0 & 7 \\
2011 & 2 & 2 & 0 & 4 \\
2012 & 5 & 0 & 0 & 5 \\
2013 & 4 & 0 & 0 & 4 \\
2014 & 0 & 0 & 1 & 1 \\
2015 & 5 & 1 & 0 & 6 \\
2016 & 5 & 1 & 0 & 6 \\
2017 & 7 & 4 & 0 & 11 \\
2018 & 6 & 4 & 0 & 10 \\
2019 & 13 & 1 & 1 & 15 \\
\hline
\end{tabular}

Source: Own elaboration based on (Ministry of Finance in Poland, 2018).

In view of the results of the survey, it can be concluded that from the perspective of economic entities, the APA can be an effective tool to reduce the risk of incorrectly set transaction pricing and to challenge the way in which the tax authorities set it. However, despite the apparent Polish increase in interest in this tool, it should be recognised that it is still not used very intensively in the tax strategies pursued. In this respect, on the basis of the 2018 data available from the European Commission and taking into account only the countries surveyed, it should be noted that a total of 68 APA were concluded in the Czech Republic during this period, 43 in Germany, 40 in France and no data on the total number of APA concluded in the Netherlands is available. (European Commission, 2018) An explanation for the discrepancies in the number of agreements can be found in the complexity and sophistication of the whole process of dealing with 
taxpayers' applications and the differences in the approach of the tax authorities in different countries to considering the agreed upon terms and conditions of a transaction as being in line with market conditions. This problem is particularly relevant to bilateral and multilateral agreements. In addition, high fees and long duration of the APA negotiations can in this respect be a factor contributing to this state of affairs. (Brychta and Sulik-Górecka, 2019) According to the Polish tax guidelines, it can take up to six months to conclude a unilateral pricing agreement, one year to reach a bilateral agreement and up to 18 months for a multilateral agreement. The degree of involvement of a country in international capital structures may also be important. In addition, obtaining the APA does not itself make the taxpayer secure against routine checks on the fulfilment of the arrangements contained in the agreement. Nevertheless, it is certainly a tool which allows the tax authorities to obtain complete information to detect tax fraud more effectively and take more effective action (Neacşu, 2017).

\section{Conclusions}

The decision to conclude an agreement related to the choice and application of the transaction pricing method provides the taxpayer with a certainty that compliance with the terms and conditions of the APA will protect it from adjustments in the transfer pricing. It should be emphasised that measures to reduce tax risk are one of the main objectives of tax management for businesses. Moreover, the adoption of an appropriate tax strategy allows the company as a whole to operate efficiently and effectively. It is therefore appropriate to recognise that the APA is a tool which can effectively influence the management of tax risk by minimising the negative tax consequences which may arise on the part the tax authorities. Nevertheless, it should also be noted that the APA procedure should be further examined for improvements as it is not free of drawbacks. The length of the procedure and the amount of information that the taxpayers must provide to the tax authorities may discourage them from doing so. As a result, every trader should consider already at the strategy stage whether the benefits of the APA outweigh the disadvantages of a complex and lengthy application process.

In addition, what is important in relation to the APA is the need to introduce certain changes in its procedure by OECD countries. It should be noted that the issue of tax avoidance is internationally unsolved problem. This is because international corporations often transfer their profits freely to tax havens. For example, despite the implementation of specific provisions counteracting this practice, Poland is in this respect, is still in line with the trend. As the commonly practice adopted by affiliated entities is to transfer their profits using differences 
in the approach to certain issues of tax law, imprecise and heterogeneous interpretations of the content of double taxation avoidance treaties, which de facto may be used to avoid taxation. In this regard, certain systemic solutions have been implemented to prevent activities resulting in tax base erosion, e.g. by implementing the ATAD directive. However, there is still a need to create or improve existing tools such as the APA in order to achieve real tax sealing effects on state budgets. In addition, the lack of effective coordination in this regard may cause some of the countries to adapt to the lobby of international corporations. As a result, these countries may begin to act as tax havens while remaining members of the European Union. Nevertheless, EU and international initiatives aimed at combating tax avoidance and evasion may increase attractiveness of the tools to reduce the tax risk of related parties and thus the tax planning decisions. Moreover, it is worth looking at the issue from the perspective of the tax administration, as the conclusion of advance pricing agreements provides tax authorities with detailed information that allows them to detect tax fraud more effectively and take more effective measures to control transfer pricing.

\section{References}

Kaniewska-Środecka, M., 2018. Zarządzanie Ryzykiem Cen Transferowych. C.H. Beck, Warszawa.

Kosierdzki, T., Piekarz R., Rynkowska A., 2019. Ceny Transferowe 2019. Mechanizmy, Dokumentacje, Raportowanie. Wolters Kluwer Polska SA., Warszawa.

Szpadzik, K., 2019. Ceny Transferowe. Wybrane Zagadnienia. Wolters Kluwer Polska SA., Warszawa.

Afik, Z., Lahav, Y., 2016. Risk Transfer Valuation in Advance Pricing Agreements Between Multinational Enterprises and Tax Authorities. Journal of Accounting, Auditing \& Finance 31 (2), 204-210.

Biernacki, K., 2017. Ryzyko Podatkowe i Instrumenty Jego Minimalizacji w Polsce. Annales Universitatis Mariae Curie-Skłodowska, Sectio H - Oeconomia 51 (5), 20-25.

Brychta, K., Sulik-Górecka, A., 2019. Legal regulation for advance pricing agreements in the Czech Republic and Poland - a comparative case study. Acta Universitatis Agriculturae Et Silviculturae Mendelianae Brunensis 67 (1), 219220 . 
Kuropka, K.: Advance Pricing Arrangements as a tax strategy tool for related entities.

Eden, L., Byrnes, W., 2018. Transfer pricing and state aid: the unintended consequences of advance pricing agreements. Transnational Corporations 25 (2), $12-14$.

Flipsen, P.H.M., Duteweert, P., 2014. BEPS Developments and EU Parent Subsidiary Directive Changes Analyzed from a Dutch Perspective. International Tax Journal 40 (6), 7-12.

Mikrut, A., Poznańska, A., 2009. Strategia Podatkowa Przedsiębiorstwa. Zeszyty Naukowe Małopolskiej Wyższej Szkoły Ekonomicznej w Tarnowie 13 (2), 229230 .

Neacşu, I., 2017. Advance Pricing Agreements and Double Taxation - Key Concepts in the Context of Transfer Pricing. Ovidius University Annals, Series Economic Sciences 17 (2), 565-570.

Walicka, M., 2012. Optymalizacja Podatkowa w Działalności Gospodarczej Małych Przedsiębiorstw. Zeszyty Naukowe Uniwersytetu Szczecińskiego. 708 (52), 272-280.

Court of Justice of the European Union, 2019. T-131/16 Belgium v Commission, EU:T:2019:91.

European Commission, 2018. Eu Joint Transfer Pricing Forum Statistics on APAs in the EU at the End of 2018. Brussels, Belgium. Available from: <ec.europa.eu/taxation_customs/sites/taxation/files/2016_jptf_apa_statistics_en.pd f>. [28 July 2020].

Organisation for Economic Co-operation and Development (OECD). 2017a. OECD Transfer Pricing Guidelines for Multinational Enterprises and Tax Administrations 2017. Paris, France.

Organisation for Economic Co-operation and Development (OECD). 2017b. Model Tax Convention on Income and on Capital. Paris, France.

Ministry of Finance in Poland, 2018. Uprzednie porozumienia cenowe (APA) Warsaw, Poland. Available from: <podatki.gov.pl/ceny-transferowe/procedurymap-i-apa-statystyki/uprzednie-porozumienia-cenowe-apa/>. [05 February 2020]. 